\title{
Investigating the potential for energy flexibility in an office building with a vertical BIPV and a PV roof system
}

\author{
Daniel Aelenei ${ }^{\mathrm{a}, \mathrm{b},{ }^{*}, \text { Rui Amaral Lopes }}{ }^{\mathrm{a}, \mathrm{b}}$, Laura Aelenei ${ }^{\mathrm{c}}$, Helder Gonçalves ${ }^{\mathrm{c}}$ \\ ${ }^{\text {a }}$ Centre of Technology and Systems/UNINOVA, Almada, Portugal \\ ${ }^{\mathrm{b}}$ Faculty of Science and Technology of Universidade Nova de Lisboa, Portugal \\ c National Energy and Geology Laboratory, Lisbon, Portugal
}

\section{A R T I C L E I N F O}

\section{Article history:}

Received 18 July 2017

Received in revised form

15 June 2018

Accepted 29 July 2018

Available online 2 August 2018

\section{Keywords:}

Building integrated photovoltaics (BIPV)

Office building

Flexible demand

Energy flexibility

Load matching

Energy storage systems (BESS)

\begin{abstract}
A B S T R A C T
Building Integrated Photovoltaics (BIPV) are becoming an attractive solution in the context of high penetration of photovoltaics (PV) in buildings caused by the strive to achieve net or nearly zero energy status. Besides retrieving solar radiation to produce electricity, BIPV also offers aesthetical advantages because of its architectural feature. This paper reports on the electrical energy performance of a passive solar office building, Solar XXI, located in Lisbon, Portugal, which has installed on the South façade a BIPV $(12 \mathrm{kWp})$ and an additional photovoltaic roof system in a nearby car park facility (12 kWp) for electricity generation. The main objective is to investigate the potential to increase load matching between energy generation and consumption and improve grid interaction for two scenarios using the energy flexibility enabled by the integration of Battery Energy Storage Systems (BESS) with capacities ranging from $13.5 \mathrm{kWh}$ to $54 \mathrm{kWh}$. To collect the required results, real consumption and generation data are used, together with numerical simulations related to the integration of the BESS. The results show that load matching and grid interaction related metrics can be significantly improved by using the energy flexibility provided by a BESS and that the implementation of such system can be economically viable for a 10 -year period.
\end{abstract}

(c) 2018 Elsevier Ltd. All rights reserved.

\section{Introduction}

\subsection{Background and motivation}

Statistics are showing that buildings are responsible for $40 \%$ of energy consumption in the EU and U.S [1]. In this context, it is of fundamental importance to identify strategies for the building stock to meet the objectives in terms of energy efficiency and climate change set by different countries [2]. Unlocking the potential of energy efficiency in the buildings sector is a priority for EU countries. One of the most important legislative instruments aiming at this is the directive 2010/31/EU [3] which requires Member States to draw up national plans for increasing the number of nearly zero-energy buildings (nZEBs). A nZEB refers to a high energy performance building of which annual primary energy consumption is covered to a very significant extent by energy from

\footnotetext{
* Corresponding author. Centre of Technology and Systems/UNINOVA, Almada, Portugal.

E-mail address: aelenei@fct.unl.pt (D. Aelenei).
}

renewable sources, including energy from renewable sources produced on-site or nearby [4].

Integrating renewable energy sources in nZEBs is the key factor to achieve the desired level of zero energy performance, but there is a global consensus that a consistent approach should first explore the available energy efficient measures [5]. Regarding the integration of renewable sources, BIPV represent an attractive solution if designed to generate electricity, generate heat to improve comfort of occupants during heating season and improve the aesthetics of the building if installed on the façade. One such building is Solar XXI, located in Lisbon, Portugal [6]. Solar XXI is an office building which integrates a variety of energy efficiency measures and strategies and has installed on the South façade a BIPV (12 kWp) and an additional photovoltaic (PV) roof system in a nearby car park facility (12 kWp) for electricity generation. Because BIPV serve dual functions, they are very attractive due to their ability to meet both the energy and the users comfort requirements at the same time.

Solar XXI has a proven record of high performance with respect of zero energy concept [7]. However, because the supply from renewable sources is governed by the availability of the respective primary energy source, there is often no correlation between 